\title{
Factors influencing consumers' light commercial vehicle purchase intention in a developing country
}

\author{
Çelik ALİ KEMAL \\ Atatürk University, Erzurum, Turkey \\ Oktay ERKAN \\ Atatürk University, Erzurum, Turkey \\ Doğan EBÜL MUHSIN
}

Ondokuz Mayıs University, Samsun, Turkey

Özhancı ÖMER

\begin{abstract}
The main objective of this paper is to determine factors affecting the intention to purchase a light commercial vehicle that may be influential in a developing country. For this purpose, a self-administered survey was conducted on 408 people living in Erzurum city, North-Eastern Turkey. The data of the survey was analyzed using binary logistic regression model due to the discrete and categorical nature of the dependent variable. Results revealed that gender, age, monthly income, household size, type of driving license, type of fuel, a significant increase in the monthly income, and costs of having SRC-K licenses were significant determinants of consumers' light commercial vehicle demand. Whilst consumers' automotive demand has been extensively studied, little research has been concentrated on light commercial vehicle demand. In this respect, the outcome of this study may provide valuable insights for the existing consumer demand literature in terms of light commercial vehicle purchase intention.
\end{abstract}

Keywords: consumer, demand, light commercial vehicle, logistic regression, Turkey.

Please cite the article as follows: Ali Kemal, C., Erkan, O., Ebül Muhsin, D. and Ömer, Ö. (2015), "Factors influencing consumers' light commercial vehicle purchase intention in a developing country", Management \& Marketing. Challenges for the Knowledge Society, Vol. 10, No. 2, pp. 148-162, DOI: 10.1515/mmcks-2015-0012.

* An earlier Turkish version of this paper was presented at "15th International Symposium on Econometrics, Operations Research and Statistics" on 22-25 May 2014, Isparta, Turkey

\section{Introduction}

The automotive industry has a leading position in emerging economies because of the recent technological developments and significant changes in social life. Automotive industry has an extensive infrastructure and automotive products have relatively high demand from for many various purposes including transportation, production and defence. As the Automotive Distributers' Association and The Economic Research Foundation of Turkey reports (2013), the total endorsement in the automotive industry is equivalent to the sixth major economy worldwide with almost fifty million employees providing a 433 billion euros contribution to all capital budgets.

Correspondence: Celik Ali Kemal akemal.celik@atau ni.edu.tr 
As an emerging economy, the automotive industry in Turkey plays an important role in the manufacturing sector. However, according to the latest market evaluation of the Turkish Automotive Distributers' Association (2015), the Turkish passenger car and light commercial vehicle (LCV) total market decreased by almost 10\% in 2014 with 767,681 units sold compared to 853,378 in 2013. Specifically, the number of LCV sales was 180,350 in 2014 with a $4.44 \%$ decrease compared to 2013. The main reasons of market share decline were associated with several indicators such as increases in exchange and interest rates, an increase in car special consumption tax rates, restrictions imposed by the Banking Regulatory and Supervisory Agency toward credit transactions, deceleration in economic growth, and weak private sector consumption and investments (Automotive Distributers' Association, 2015). Fortunately, the results of a very recent survey on nearly 200 automotive executives indicate that a new adjustment of taxes on automobile sales will be the top priority issue in the next five years. Moreover, most of the executives in the Turkish automotive industry foresee a market growth despite a decline of growth rate anticipation (KPMG Turkey, 2014). Another recent report on automotive demand forecast in Turkey (Kurcova et al., 2012) exhibits that consumers' automobile demand in Turkey is strictly sensitive to Turkish economic progress. At this point, periodical analyses of consumer behaviour may provide valuable insights for both present and future automotive market policies.

Whilst consumers' automobile purchase decisions have been extensively studied in the existing literature, little research specifically examined their LCV demand. This paper aims to determine the key factors affecting consumers' purchase decisions in an emerging economy with an emphasis on LCV demand. The next section reviews the existing literature concentrating on consumers' purchase decision in the automotive industry. The methodology section gives theoretical information about the conceptual framework of the analysis used in the study. This section also introduces the sample and data collection. The results section interprets the results of the statistical estimations. This paper concludes with a discussion of the results and suggestions for policy makers.

\section{Literature review}

There is a fairly large literature considering various aspects of factors that may influence consumers' vehicle purchase intention or decisions, regarding various types of vehicles. Especially, several demographic factors were frequently highlighted as significant contributors to consumers' motor vehicle purchase decisions. Not surprisingly, monthly household or individual income was found as one of the major determinants of consumers' vehicle ownership decisions (Ede and Panigrahi, 2000; Lam et al., 2000; Romilly et al., 2001; Yılmaz, 2001; Choo and Mokhtarian, 2004; Kumar and Krishna Rao, 2006; Potoglou and Kanaroglou, 2008a; Bhat et al., 2009; Nolan, 2010; Prieto and Caemmerer, 2013; Wong, 2013). Respondents' age group gave significant evidence to explain consumers' vehicle purchase decisions in early studies (Ede and Panigrahi, 2000; Choo and Mokhtarian, 2004; Cao et al., 2006; Hackbarth and Madlener, 2013; Prieto and Caemmerer, 2013; Sanko et al., 2014). Gender was found as an important factor that may influence consumers' vehicle demand (Ede and Panigrahi, 2000; Choo and Mokhtarian, 2004; Bhat and Sen, 2006, Cao et al., 2006; Prieto and Caemmerer, 
2013; Sanko et al., 2014). Household size can be an important explanatory variable in examining consumers' purchase behaviour and many early studies (Choo and Mokhtarian, 2004; Kumar and Krishna Rao, 2006; Potoglou, 2008; Potoglou and Kanaroglou, 2008a; Bhat et al., 2009; Prieto and Caemmerer, 2013; Wong, 2013; Sanko et al., 2014) found significant association between household size and vehicle type ownership. There has been recent work in which respondents' educational level was demonstrated as the significant contributor to consumers' vehicle ownership (Ede and Panigrahi, 2000; Yllmaz, 2001; Choo and Mokhtarian, 2004; Cao et al., 2006; Potoglou, 2008; Hackbarth and Madlener, 2013; Prieto and Caemmerer, 2013). Apart from these determinants, several other key factors such as occupational status (Yllmaz, 2001; Bhat and Sen, 2006; Sanko et al., 2014), presence of children in the family (Bhat and Sen, 2006; Cao et al., 2006; Bhat et al., 2009; Wong, 2013), number of working adults (Potoglou and Kanaroglou, 2008a; Wong, 2013), number of persons with driving license (Potoglou and Kanaroglou, 2008b), and annual license fee (Lam et al., 2000) were also included as significant influence on the consumers' vehicle purchase decisions or intentions.

Recent works (Kircova et al., 2012) found that the yearly increase of automobile demand was related to the increase of monthly income and population along with income distribution, as high-income consumers were more likely to create automobile demand. Earlier research (Yllmaz, 2001; Choo and Mokhtarian, 2004; Cao et al., 2006; Potoglou, 2008; Potoglou and Kanaroglou, 2008a; Nayum and Klöckner, 2014) found that consumers' vehicle choice was differentiated by several factors such as gender, different age groups, educational or income levels, household size or occupational status for various type of vehicles. Bhat and Sen (2006) found that higher income consumers were more likely to have passenger cars, SUVs and minivans and they also stated that the presence of children had a significant effect on consumers' purchase decisions, because parents tend to have SUVs and minivans for safety and comfort. Gender and employment status were also found as statistically significant influencers. Another similar study (Bhat et al., 2009) found that high income consumers were less likely to buy an older vehicle. Household size was also associated with consumers' purchase decisions. Presence of children was also found as an important determinant of car ownership in a recent study (Nolan, 2010). Dargay (2001) suggested that a significant rise of the income level also increases consumers' car ownership. Recent studies (Matas and Raymond, 2008) underlined that car ownership increases with a decline of income elasticity and households from rural areas were less sensitive to lower income than their counterparts living in urban areas. Other studies (Dargay and Gately, 1999; Dargay, 2002; Medlock III and Soligo, 2002; Nolan, 2010) have also emphasized the impact of income elasticity on consumers' motor vehicle purchase decision. Consumers' purpose of car use, and attachment to cars were found as other specific indicators of purchase decisions (Baltas and Saridakis, 2013).

A very recent survey highlights that the top priority for purchasing motor vehicles for most of the consumers was fuel efficiency and almost $70 \%$ of them also mentioned longer lasting performance. The use of alternative fuel technologies were also associated with consumers' purchase decisions (KPMG International, 2014). Other previous works (Potoglou, 2008; Potoglou and Kanaroglou, 2008b; Bhat et al., 2009; Dagsvik and Liu, 2009; Qian and Soopramanien, 2011; Hess et al., 
2012; Hackbarth and Madlener, 2013; Mabit, 2014; Liu et al., 2014; Nayum and Klöckner, 2014; Tanaka et al., 2014; Xu et al., 2015) also demonstrated that fuel efficiency and rising fuel prices had an effect on consumers' vehicle choice as well as technological development and tax reforms. Apart from these key factors, the level of carbon emissions also had a significant impact on the buyers' decision (Nayum et al., 2013). The consumers' ecological car interests were also associated with the chosen car type in other earlier research (Oliver and Lee, 2010; Baltas and Saridakis, 2013; Xu et al., 2015). The country of origin was considered as one of the significant determinants of the consumers' motor vehicle purchase intentions (Alper and Mumcu, 2007; Urbonavičius et al., 2007; Thanasuta et al., 2009; Özçam and Sağlık Özçam, 2012). Comfort, safety and modernity were also found to be significant (Sedzro et al., 2014).

\section{Research methodology \\ Logistic regression model}

Some of the most interesting response variables in the social sciences are binary or dichotomous due to the crudeness of measurement. However, the theoretical idea that probabilities are linear in independent variables is not practically applicable and for a binary response, the use of a linear regression model does not seem to be the optimum strategy (DeMaris, 2004). The logistic regression model has been long employed in many fields over the last decade when the outcome is discrete and taking two or more possible values. Suppose the quantity $\pi(x)=E(Y \mid x)$ represents the conditional mean of $Y$ given $x$ since the logistic distribution is used. In this circumstance, the specific form of the logistic regression model is the following:

$$
\pi(x)=\frac{e^{\beta_{0}+\beta_{1} x}}{1+e^{\beta_{0}+\beta_{1} x}}
$$

Furthermore, the logit transformation in terms of $\pi(x)$ can be defined as:

$$
g(x)=\ln \left[\frac{\pi(x)}{1-\pi(x)}\right]=\beta_{0}+\beta_{1} x
$$

In Equation (2), $g(x)$ will have many of the properties of a linear regression model. This logit is linear in its parameters, may be continuous, and may range from $-\infty$ to $+\infty$ with respect to the behavior of $x$ (Hosmer and Lemeshow, 2000). Actually, the sign of $\beta_{1}$ determines whether the logit is increasing or decreasing when $x$ increases. The odds increase multiplicatively by $e^{\beta}$ for every one unit increase in $x$. In this respect, $e^{\beta}$ is considered as the odds ratio (OR) which implies the odds at $X=x+1$ divided by the odds at $X=x$ (Agresti, 2002).

Suppose a sample of $n$ independent observations of the pair $\left(x_{i}, y_{i}\right), i=1,2$,. $, \cdots, n$, where $x_{i}$ denotes the value of the independent variable for the $i$ th subject and $y_{i}$ denotes the value of a binary outcome variable. Since the observations are assumed to be independent, the likelihood function can be obtained as foollows: 
and the log-likelihood function can be defined as the following:

$$
L(\beta)=\ln [l(\beta)]=\sum_{i=1}^{n}\left\{y_{i} \ln \left[\pi\left(x_{i}\right)\right]+\left(1-y_{i}\right) \ln \left[1-\pi\left(x_{i}\right)\right]\right\}
$$

This expression is differentiated with respect to $\beta_{0}$ and $\beta_{1}$ and set the resulting formulas equal to zero to find the value of $\beta$ that maximizes the corresponding equation (Hosmer and Lemeshow, 2000). Due to the nonlinearity of the model, the discrete change in the predicted probabilities are highly recommended for a given change in an independent variable. Since $\operatorname{Pr}\left(y=1 \mid x, x_{k}\right)$ represents the probability of an event given $x$, noting in particular the value of $x_{k}$ and $\operatorname{Pr}\left(y=1 \mid x, x_{k}+\delta\right)$ represents the probability of the event with only $x_{k}$ increased by some quantity $\delta$, then the discrete change for a change of $\delta$ in $x_{k}$ equals to

$$
\frac{\Delta \operatorname{Pr}(y=1 \mid x)}{\Delta x_{k}}=\operatorname{Pr}\left(y=1 \mid x, x_{k}+\delta\right)-\operatorname{Pr}\left(y=1 \mid x, x_{k}\right)
$$

which describes the marginal effect of an independent variable with dummy variables (Long and Freese, 2001).

\section{Study design, sample and data collection}

This paper aims to ascertain factors affecting consumers' automotive demand and an emphasis is placed on consumers' LCV demand in Erzurum city, Turkey. For this purpose, a self-administered written survey was conducted on 408 respondents living in Erzurum city center, between November 2013 and February 2014. The corresponding survey performs a simple random sampling method to keep the level of representation both proportional and as high as possible. The corresponding survey involves detailed questions about demographic attributes of the respondents and possible factors that may influence their LCV demand. The Cronbach alpha value of the survey was found 0.88 , satisfying the minimum 0.70 recommended by Nunnally (1978) for relatively high internal consistency. According to Address Based Population Registration System Statistics (TurkStat, 2013), the city center population of Erzurum was 394,684 during the sampling period. The minimum sample size of the survey was calculated with respect to the following formula:

$$
n=\frac{N P Q Z^{2}}{(N-1) d^{2}+P Q Z^{2}}
$$

where $n$ denotes the sample size; $N$ denotes the population size; $P=$ the probability of the occurrence for a given event; $Q=1-P ; Z$ denotes the test statistic under the $(1-\alpha) \%$ significance level; and finally $d$ denotes the tolerance. In this respect, the 
minimum representative sample size of the survey can be calculated as follows (Yamane, 1967):

$$
n=\frac{(394,684)(0.5)(0.5)(1.96)^{2}}{(394,684-1)(0.05)^{2}+(0.5)(0.5)(1.96)^{2}} \cong 384
$$

As shown in Equation (7), 408 respondents exceed the number of minimum sample size.

The dependent variable of the survey was the LCV purchase intention in the near future where 1 accounts for 'yes' and 0 accounts for 'no'. As the dependent variable has the characteristics of a discrete and binary response variable, the utilized data was analyzed using the binary logistic regression model. The fitted model was statistically significant at $90 \%$ significance level and higher, which implies that the corresponding model is statistically correct. In addition, a multicollinearity test was performed before fitting the model and no serious multicollinearity was found among the independent variables.

\section{Research results \\ Descriptive statistics}

Table 1 presents the descriptive statistics for both the dependent variable and the independent variable used in the fitted model. As shown in Table 1, almost 38\% of the respondents had an intention to purchase a LCV in the near future. Most of the respondents (83.58\%) were men, and more than $40 \%$ of them (41.67\%) were aged between 30 and 39 . More than half of the respondents $(62.50 \%)$ were highly educated, and $54.90 \%$ were, at that moment, working as office workers. The households of $43.87 \%$ of the respondents involved three or four individuals. Almost half of the respondents (40.93\%) had a monthly individual income between 2,000 and 3,000 Turkish liras (TL) and more than half of them (56.13\%) had more than 3,000 TL monthly household income. A majority of the respondents (73.28\%) held a class B driving license which was used to drive a passenger car. Also $30.64 \%$ of them were using diesel fuel for their motor vehicles.

According to descriptive statistics, almost $68 \%$ of the respondents think that the price of a new vehicle would have a definite effect on their decision of purchasing or nor an LCV. Almost 68\% of them said that the price of a second hand vehicle also had an effect on their purchase decision. Most of the respondents (65.93\%) mentioned the importance of low special fuel consumption taxes (SCT) when talking about their LCV purchase intentions. The decision was made mostly considering the fuel consumption for $82.35 \%$ of the respondents. Most of them (76.12\%) also think that maintenance and repair costs of a LCV would be decisive when purchasing a car.

More than half of the respondents (55.88\%) think that joint vehicle costs would be influential or definitely influential on their LCV purchase intention. Most of the respondents think that passenger and carrier capacity (64.7\%) and use of a LCV as a passenger car (69.86\%) would significant or definitely significant on their purchasing intention. Nearly half of them think that costs of SRC and K licenses (46.32\%), a significant increase on monthly income (48.53\%), and a significant decrease on fuel prices (53.67\%) would have a significant effect on their LCV purchase intentions. Descriptive statistics indicated that $24.02 \%$ think that a 
future public transport improvement would be somewhat determinant on a LCV purchase intention, while $23.04 \%$ think that such an improvement would definitely not affect their future LCV demand. Finally, more than half of the respondents $(51.47 \%)$ think that a decline in rental costs would not have a significant effect on their LCV future purchase decisions.

\section{Results of the statistical estimation}

Table 2 exhibits the results of a binary logistic regression to determine key factors that may influence the respondents' LCV purchase intention. The model had respectable goodness of fit and McFadden $\mathrm{R}^{2}$ values for a categorical data analysis. The confidence intervals (CI) in Table 2 present both lower and upper values of the ORs. Table 3 also represents marginal effect values of independent variables and both ORs and marginal effect values of the same variables would be interpreted simultaneously for simplicity and brevity.

The results of the statistical estimations revealed that gender was a significant contributor in consumers' LCV purchase intention in the near future. Accordingly, men were nearly four times (OR $=3.94, p<.001,90 \% \mathrm{CI}=1.82-$ 8.53) more likely to have future LCV purchase intentions than women. Marginal effects also indicated that the probability of a future LCV purchase intention increases by $24.8 \%$ for men. This result is not surprising since the relatively higher interest of men on various types of motor vehicles and higher rate of men respondents. The respondents' age group was also a significant influencing factor that may have an effect on a possible LCV purchase. Specifically, respondents aged between 30 and 39 were nearly 0.4 times (OR $=0.43, p<.10,90 \% \mathrm{CI}=0.20-0.89$ ) less likely to have a future LCV purchase intention than respondents older than 49 years. This probability decreases by $18.4 \%$ for the same age group. Similarly, respondents aged between 40 and 49 were 0.45 times $(\mathrm{OR}=0.45, p<.10,90 \% \mathrm{CI}=$ $0.21-0.97)$ to have a LCV purchase intention than the reference age group. The probability of these respondents decreases by $16.1 \%$ with respect to marginal effects. All monthly individual income categories were found to increase respondents' future LCV purchase intentions. Particularly, respondents who had monthly individual income between 1,000 and 2,000 TL were nearly 2.5 times (OR $=2.53, p<.10,90 \% \mathrm{CI}=1.04-6.16)$ more likely to have a future LCV intention than relatively low income respondents with monthly income less than 1,000 TL. Respondents who had a monthly income between 2,000 and 3,000 TL and more than 3,000 TL were also almost three (OR $=2.91, p<.10,90 \% \mathrm{CI}=1.09-7.78)$ and almost 3.3 times (OR $=3.26, p<.10,90 \% \mathrm{CI}=1.07-9.91)$ more likely to have an LCV demand in the near future than respondents who had less than 1,000 TL, respectively. The probability of having a future LCV demand increases by $24.1 \%$ for respondents who have a monthly income between 2,000 and 3,000 TL and by $27.7 \%$ for respondents who had monthly incomes more than 3,000 TL, respectively.

Table 1. Descriptive statistics of variables

\begin{tabular}{|l|c|l|c|}
\hline Variable & Frequency (\%) & Variable & Frequency (\%) \\
\hline $\begin{array}{l}\text { (1) Intention to purchase } \\
\text { an LCV }\end{array}$ & & (14) Fuel consumption & \\
\hline Yes & $155(37.99)$ & Definitely not influential ${ }^{a}$ & $14(3.43)$ \\
\hline $\mathrm{No}^{\mathrm{s}}$ & $253(62.01)$ & Not influential & $17(4.17)$ \\
\hline (2) Gender & & Somewhat influential & $41(10.05)$ \\
\hline
\end{tabular}




\begin{tabular}{|c|c|c|c|}
\hline Male & $341(83.58)$ & Influential & $104(25.49)$ \\
\hline Females & $67(16.42)$ & Definitely influential & $232(56.86)$ \\
\hline (3) Age group & & (15) Maintenance and repair costs & \\
\hline Age $<30$ & $93(22.79)$ & Definitely not influentiala & $16(3.92)$ \\
\hline $30 \leq$ Age $\leq 39$ & $170(41.67)$ & Not influential & $25(6.13)$ \\
\hline $40 \leq$ Age $\leq 49$ & $87(21.32)$ & Somewhat influential & $56(13.73)$ \\
\hline Age $>49 \mathrm{~s}$ & $58(14.22)$ & Influential & $128(31.27)$ \\
\hline (4) Educational level & & Definitely influential & $183(44.85)$ \\
\hline $\begin{array}{l}\text { Literate/primary } \\
\text { education }^{\mathrm{s}}\end{array}$ & $50(12.25)$ & (16) Vehicle costs as expenses & \\
\hline Secondary education & $103(25.25)$ & Definitely not influentiala $^{a}$ & $54(13.24)$ \\
\hline Higher education & $255(62.50)$ & Not influential & $42(10.29)$ \\
\hline (5) Occupation & & Somewhat influential & $84(20.59)$ \\
\hline Self-employed & $158(38.73)$ & Influential & $97(23.77)$ \\
\hline Worker/officer & $224(54.90)$ & Definitely influential & $131(32.11)$ \\
\hline Otherss & $26(6.37)$ & (17) Passenger and carrier capacity & \\
\hline (6) Household size & & Definitely not influentiala & $35(8.58)$ \\
\hline $\begin{array}{l}\text { Less than three } \\
\text { individual }(s)^{\mathrm{a}}\end{array}$ & $55(13.48)$ & Not influential & $34(8.33)$ \\
\hline $3-4$ individuals & $179(43.87)$ & Somewhat influential & $75(18.38)$ \\
\hline $\begin{array}{l}\text { More than four } \\
\text { individuals }\end{array}$ & $174(42.65)$ & Influential & $114(27.94)$ \\
\hline $\begin{array}{l}\text { (7) Monthly individual } \\
\text { income }\end{array}$ & & Definitely influential & $150(36.76)$ \\
\hline Income $<1000 \mathrm{TL}^{\mathrm{a}}$ & $32(7.84)$ & (18) Use as a passenger car & \\
\hline $\begin{array}{l}1000 \mathrm{TL} \leq \text { Income }<2000 \\
\mathrm{TL}\end{array}$ & $109(26.72)$ & Definitely not influentiala & $20(4.90)$ \\
\hline $\begin{array}{l}2000 \mathrm{TL} \leq \text { Income } \leq 3000 \\
\mathrm{TL}\end{array}$ & $167(40.93)$ & Not influential & $26(6.37)$ \\
\hline Income $>3000 \mathrm{TL}$ & $100(24.51)$ & Somewhat influential & 77 (18.87) \\
\hline $\begin{array}{l}\text { (8) Monthly household } \\
\text { income }\end{array}$ & & Influential & $125(30.64)$ \\
\hline Income $<2000 \mathrm{TL}^{\mathrm{a}}$ & $58(14.22)$ & Definitely influential & $160(39.22)$ \\
\hline $\begin{array}{l}2000 \mathrm{TL} \leq \text { Income } \leq 3000 \\
\mathrm{TL}\end{array}$ & $121(29.66)$ & (19) Cost of SRC and K licenses & \\
\hline Income $>3000 \mathrm{TL}$ & $229(56.13)$ & Definitely not influentiala $^{a}$ & $70(17.16)$ \\
\hline (9) Driving license & & Not influential & $55(13.48)$ \\
\hline Class B & $299(73.28)$ & Somewhat influential & $94(23.04)$ \\
\hline Class E & $74(18.14)$ & Influential & $88(21.57)$ \\
\hline Others $^{\mathrm{a}}$ & $35(8.58)$ & Definitely influential & $101(24.75)$ \\
\hline (10) Type of fuel & & $\begin{array}{l}\text { (20) Significant increase of monthly } \\
\text { income }\end{array}$ & \\
\hline $\begin{array}{l}\text { Others/no motor } \\
\text { vehiclea }^{\text {a }}\end{array}$ & 115 (28.19) & Definitely not influentiala & $74(18.14)$ \\
\hline Diesel & $125(30.64)$ & Not influential & $58(14.22)$ \\
\hline Oil & $76(18.63)$ & Somewhat influential & $78(19.12)$ \\
\hline LPG & $92(22.55)$ & Influential & $98(24.02)$ \\
\hline (11) Price of new vehicles & & Definitely influential & $100(24.51)$ \\
\hline Definitely not influentiala $^{a}$ & $34(8.33)$ & $\begin{array}{l}\text { (21) Significant decrease of fuel } \\
\text { prices }\end{array}$ & \\
\hline Not influential & $27(6.62)$ & Definitely not influential $^{\mathrm{a}}$ & $60(14.71)$ \\
\hline Somewhat influential & $70(17.16)$ & Not influential & $50(12.25)$ \\
\hline Influential & $122(29.90)$ & Somewhat influential & $79(19.36)$ \\
\hline Definitely influential & $155(37.99)$ & Influential & $97(23.77)$ \\
\hline $\begin{array}{l}\text { (12) Price of a second-hand } \\
\text { vehicle }\end{array}$ & & Definitely influential & $122(29.90)$ \\
\hline Definitely not influentiala & $29(7.11)$ & $\begin{array}{l}\text { (22) Enhancements on public } \\
\text { transport }\end{array}$ & \\
\hline Not influential & $33(8.09)$ & Definitely not influentiala $^{\mathrm{a}}$ & $94(23.04)$ \\
\hline Somewhat influential & $88(21.57)$ & Not influential & $75(18.38)$ \\
\hline Influential & $136(33.33)$ & Somewhat influential & $98(24.02)$ \\
\hline Definitely influential & $122(29.90)$ & Influential & $81(19.85)$ \\
\hline (13) Low SCT & & Definitely influential & $60(14.71)$ \\
\hline Definitely not influentiala $^{\mathrm{a}}$ & $32(7.84)$ & (23) Decrease of rental costs & \\
\hline Not influential & $28(6.86)$ & Definitely not influentiala & $124(30.39)$ \\
\hline
\end{tabular}




\begin{tabular}{|l|r|l|l|}
\hline Somewhat influential & $79(19.36)$ & Not influential & $86(21.08)$ \\
\hline Influential & $132(32.35)$ & Somewhat influential & $74(18.14)$ \\
\hline Definitely influential & $137(33.58)$ & Influential & $67(16.42)$ \\
\hline & & Definitely influential & $57(13.97)$ \\
\hline
\end{tabular}

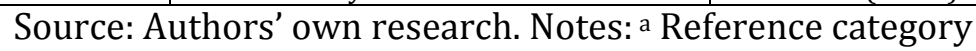

Table 2. Results of logistic regression for factors influencing consumers' LCV purchase intention

\begin{tabular}{|c|c|c|c|c|}
\hline Independent variable & Coefficient & OR & Std Err & $90 \% \mathrm{CI}$ \\
\hline Gender; male & $1.371^{\mathrm{a}}$ & 3.94 & 1.851 & $1.82-8.53$ \\
\hline Age group; $30 \leq$ Age $\leq 39$ & $-0.856^{c}$ & 0.43 & 0.190 & $0.20-0.89$ \\
\hline Age group; $40 \leq$ Age $\leq 49$ & $-0.703^{c}$ & 0.45 & 0.209 & $0.21-0.97$ \\
\hline Monthly individual income; $1000 \mathrm{TL} \leq$ Income $<2000 \mathrm{TL}$ & $0.929 \mathrm{c}$ & 2.53 & 1.368 & $1.04-6.16$ \\
\hline Monthly individual income; $2000 \mathrm{TL} \leq$ Income $\leq 3000 \mathrm{TL}$ & $1.069^{\mathrm{c}}$ & 2.91 & 1.740 & $1.09-7.78$ \\
\hline Monthly individual income; Income $>3000 \mathrm{TL}$ & $1.181^{\mathrm{c}}$ & 3.26 & 2.203 & $1.07-9.91$ \\
\hline Household size; $3-4$ individuals & $0.926^{\mathrm{c}}$ & 2.52 & 1.231 & $1.13-5.63$ \\
\hline Household size; more than four individuals & $1.478^{\mathrm{a}}$ & 4.38 & 2.144 & $1.96-9.80$ \\
\hline Driving license; class E & $1.124^{\mathrm{b}}$ & 3.08 & 1.623 & $1.29-7.33$ \\
\hline Type of fuel; oil & $-0.878^{b}$ & 0.42 & 0.171 & $0.21-0.82$ \\
\hline Type of fuel; LPG & $-0.950^{\mathrm{b}}$ & 0.39 & 0.152 & $0.20-0.74$ \\
\hline Cost of SRC and K licenses; definitely influential & $-0.200^{c}$ & 0.82 & 0.086 & $0.69-0.97$ \\
\hline $\begin{array}{l}\text { Significant increase of monthly income; definitely } \\
\text { influential }\end{array}$ & $0.363^{\mathrm{a}}$ & 1.44 & 0.180 & $1.17-1.77$ \\
\hline Constant term & $-3.838^{a}$ & -- & 1.326 & -- \\
\hline \multicolumn{5}{|l|}{ Summary statistics } \\
\hline Number of observations: 408 & -- & -- & -- & -- \\
\hline Log-likelihood at zero: -284.000 & -- & -- & -- & -- \\
\hline Log-likelihood at convergence: -222.041 & -- & -- & -- & -- \\
\hline McFadden $\mathrm{R}^{2}: 0.26$ & -- & -- & -- & -- \\
\hline Adjusted McFadden $\mathrm{R}^{2}: 0.20$ & -- & -- & -- & -- \\
\hline Goodness of fit value: 0.48 & -- & -- & -- & -- \\
\hline
\end{tabular}

Source: Authors' own research. Notes: a significant at 99\%; ${ }^{\mathrm{b}}$ significant at $95 \%$; significant at $90 \%$.

Table 3. Marginal effects of independent variables

\begin{tabular}{|l|r|r|}
\hline Independent variable & Marginal effect & Std Err \\
\hline Gender; male & $24.8 \%^{\mathrm{a}}$ & 0.063 \\
\hline Age group; $30 \leq$ Age $\leq 39$ & $-18.4 \%^{\mathrm{b}}$ & 0.092 \\
\hline Age group; $40 \leq$ Age $\leq 49$ & $-16.1 \%^{\mathrm{c}}$ & 0.084 \\
\hline Monthly individual income; $1000 \mathrm{TL} \leq$ Income $<2000 \mathrm{TL}$ & $21.6 \%^{\mathrm{c}}$ & 0.128 \\
\hline Monthly individual income; $2000 \mathrm{TL} \leq$ Income $\leq 3000 \mathrm{TL}$ & $24.1 \%^{\mathrm{c}}$ & 0.133 \\
\hline Monthly individual income; Income $>3000 \mathrm{TL}$ & $27.7 \%^{\mathrm{c}}$ & 0.159 \\
\hline Household size; $3-4$ individuals & $20.7 \% \mathrm{c}^{\mathrm{c}}$ & 0.107 \\
\hline Household size; more than four individuals & $32.8 \%^{\mathrm{a}}$ & 0.103 \\
\hline Driving license; class E & $26.7 \%^{\mathrm{b}}$ & 0.126 \\
\hline Type of fuel; oil & $-17.4 \%^{\mathrm{b}}$ & 0.071 \\
\hline Type of fuel; LPG & $-18.9 \%^{\mathrm{a}}$ & 0.068 \\
\hline Cost of SRC and K licenses; definitely influential & $-4.4 \%^{\mathrm{c}}$ & 0.023 \\
\hline $\begin{array}{l}\text { Significant increase on monthly income; definitely } \\
\text { influential }\end{array}$ & $8.1 \%{ }^{\mathrm{a}}$ & 0.028 \\
\hline
\end{tabular}

Source: Authors' own research. Notes: a significant at 99\%; b significant at $95 \%$; c significant at $90 \%$.

Household size was found as another significant key factor of consumers' future LCV demand. On one hand, when household size was between three and four individuals, respondents were almost 2.5 times $(\mathrm{OR}=2.52, p<.10,90 \% \mathrm{CI}=$ 1.13 - 5.63) more likely to have an LCV ownership intention. On the other hand, 
this probability increases by $20.7 \%$. Respondents who have more than four individuals in their family were almost 4.4 times (OR $=4.38, p<.01,90 \% \mathrm{CI}=1.96$ - 9.80) more likely to have an LCV in the near future than respondents who have less than three individuals in their family. According to marginal effects, the corresponding probability increases by 32.8\%. Driving license had an increasing impact on consumers' future LCV purchase decisions. Specifically, respondents who had class E driving license were almost three times $(\mathrm{OR}=3.08, p<.05,90 \% \mathrm{CI}$ $=1.29-7.33$ ) more likely to buy an LCV. The probability of an LCV purchase intention increases by $26.7 \%$ for respondents holding a class E driving license. This statistically significant contribution of several demographic results is consistent with many earlier studies (Choo and Mokhtarian, 2004; Cao et al., 2006; Potoglou, 2008; Potoglou and Kanaroglou, 2008a; Nayum and Klöckner, 2014).

The results of the statistical estimations indicated that the type of fuel would be a significant contributor of respondents' future LCV purchase intentions. This result shows consistency with many prior work (Potoglou, 2008; Bhat et al., 2009; Dagsvik and Liu, 2009; Qian and Soopramanien, 2011; Hackbarth and Madlener, 2013; Mabit, 2014; Liu et al., 2014; Nayum and Klöckner, 2014; Tanaka et al., 2014; Xu et al., 2015). Accordingly, when type of fuel was oil, respondents were 0.42 times $(\mathrm{OR}=0.42, p<.05,90 \% \mathrm{CI}=0.21-0.82$ ) less likely to have an intention to purchase an LCV than in the case of other types of fuel. The probability of having such an intention decreases by $17.4 \%$ with respect to marginal effects. Oil prices were relatively high in Turkey, so this was an expected result. Interestingly, respondents were almost 0.4 times $(\mathrm{OR}=0.39, p<.05,90 \% \mathrm{CI}=0.20$ - 0.74) less likely to have an LCV purchase intention when the type of fuel was LPG. As LPG is the relatively cheapest fuel in Turkey, it is highly preferred by most of the drivers. The cost of having an LPG tank in a motor vehicle and the potential security issues of this fuel for the road traffic might have been some reasons of respondents' reduced preference for this type of fuel. The costs of SRC and $\mathrm{K}$ licenses were a significant influencer of consumers' LCV purchase intention. Respondents were 0.82 times (OR $=0.82, p<.10,90 \% \mathrm{CI}=0.69-0.97$ ) less likely to have an LCV purchase intention when the costs of SRC and $\mathrm{K}$ licenses were under consideration. This probability decreases by $4.4 \%$ for these responses. SRC and $\mathrm{K}$ licenses were strictly obliged to use a motor vehicle for commercial purposes and respondents might have been intending to own an LCV for a passenger car purpose. Although, it was not statistically significant in the final fitted logistic regression model, most of the respondents think that the use of an LCV as a passenger car was influential or definitely influential on their intentions. Further particular research is definitely needed to explain respondents' similar decisions. Finally, a significant increase of monthly income was found to have impact on LCV purchase intentions. In this circumstance, respondents were 1.44 times (OR $=1.44, p<.01,90 \% \mathrm{CI}=1.17-1.77$ ) more likely to intend to buy an LCV.

\section{Conclusions}

The automotive industry is one of the most rapidly increasing sectors of the emerging countries, along with recent technological advances. When the crucial contribution of this industry to emerging economies is considered, sustainable development in the automotive industry has to be accomplished. Consumers' 
decisions on automotive products are one of the factors influencing for the sustainable growth of the industry and their future behaviours should be periodically examined to compensate their expectations. The main objective of this paper is to determine the factors affecting consumers' future purchase intentions of automotive products with a particular focus on consumer LCV demand. Although automotive products demand was extensively studied in the existing literature, little attention was paid to LCV demand compared to its relatively high sales in emerging economies like Turkey. The results of a survey conducted in one of the municipalities of Turkey may be insightful for future LCV demand research and may fill the significant gap for both consumer behaviour and automotive market literature. As the dependent variable of the data obtained from the survey has a discrete and binary nature, a logistic regression analysis was employed.

The results of the statistical estimations reveal that consumers' demographic attributes as well as the type of fuel and some obligations to have an LCV, have a significant effect on their LCV purchase intentions. Automotive distributers and other authorized policy makers in Turkey will continue to keep focusing on the male consumers in the automotive market. However, future marketing policies may fulfil female drivers' expectations such as introducing the usefulness of LCVs for female consumers especially as a passenger car. Results also indicate that consumers aged younger than 49 years did not intend to own an LCV in the near future. More sportive LCV models that can be intensively used for passenger transport purposes may influence the future decisions of both female and younger consumers. The current LCV market policies can be considered as successful for middle income consumers since an LCV purchase seems to be included in their future plans. Recent technological advances allow automotive distributers to produce more comfortable and sophisticated LCVs, and that may contribute to a positive change on high income consumers' future purchases. This suggestion is also highlighted in a prior research as a significant factor of car purchase (Sedzro et al., 2014). Low-cost LCVs with less comfort may also change low income consumers' decisions along with a possible significant income increase. High SCTs have been extensively reported as one of the most important barriers on the development of the Turkish automotive industry (Kırcova et al., 2012; Kitapcl et al., 2014; KPMG Turkey, 2014; Automotive Distributers' Association, 2015). A possible re-adjustment on this issue may also accelerate current Turkish LCV market sales that were on a decreasing trend in 2014.

As the results of the present study indicate, more crowded households are more likely to own an LCV. The presentation of LCVs as a convenient family vehicle may persuade consumers with bigger households to buy more LCVs. The degree of influence of this suggestion is confirmed by another result of this study. Consumers holding a class $\mathrm{E}$ driving license are more likely to have an intention to own an LCV in the near future, although LCVs can be driven with a class B passenger car driving license. It seems that consumers still assess LCVs as a commercial purpose vehicle. The possible enlargement of this image with successful future marketing policies may be useful for higher LCV sales. As results suggest, LCVs with oil and LPG are not generally preferred by consumers. Oil prices in Turkey are very high, but recent political developments led to the decline of these prices. This may contribute to the increase of automotive products sales including LCVs. Future research is actually needed to decide a clear explanation of the consumers' type of 
fuel preference. Additionally, the use of hybrid vehicles can be encouraged by relevant marketing policies which are not popular in Turkey, yet. Fortunately, the intensive use of hybrid vehicles is expected in the near future. On the other hand, a possible decline of the costs of SRC and $\mathrm{K}$ licenses may increase the intention of consumers' LCV purchase for commercial purposes. This result is in line with an early work (Lam et al., 2000).

This study has various limitations. The survey was limited to a selected region in a limited time period. Similar surveys can be periodically conducted to capture both city centre and other districts of Erzurum. As one of the largest cities in its region, the full coverage of the city with an increased sample size may give valuable information about the North-East of Turkey including some other variables such as the presence of children in the family, number of working adults and country of origin. More attention should be paid to future LCV researches in the country if the sales and contribution of LCVs on Turkish economy are considered. A cross-city or a cross-country comparison of consumers' future LCV purchase intentions may be encouraged in order to evaluate current marketing policies and to decide on future attempts. In this sense, a comparison of similar emerging markets may provide a valuable tool for the growth of these markets. Apart from binary models, other different ordered response models such as ordered logit model, generalized ordered logit model, partial constrained ordered logit model and/or heterogeneous choice model can be employed by considering some categorical variables as a dependent variable with an ordered nature.

\section{References}

Agresti, A. (2002), Categorical Data Analysis, John Wiley \& Sons, New Jersey.

Alper, C.E. and Mumcu, A. (2007), "Interaction between price, quality and country of origin when estimating automobile demand: The case of Turkey", Applied Economics, Vol. 39, No. 4, pp. 1789-1796.

Automotive Distributers' Association. (2015), Passenger Car and Light Commercial Vehicle Market Press Review, January 07, 2015, available at www.odd.org.tr/folders/2837/categorial1docs/1056/Press\%20Release\%2 07\%20Jan\%202015.pdf (accessed January 21, 2015).

Automotive Distributers' Association and The Economic Research Foundation of Turkey, (2013), Dünya ve Türkiye Otomotiv Sektörü 2013 (in Turkish), available at: www.odd.org.tr/folders/2837/categorial1docs/821/ic\%20 dokumanlar .pdf, (accessed January 21, 2015).

Baltas, G. and Saridakis, C. (2013), "An empirical investigation of the impact of behavioural and psychographic consumer characteristics on car preferences: An integrated model of car type choice", Transportation Research Part A: Policy and Practice, Vol. 54, pp. 92-110.

Bhat, C.R. and Sen, S. (2006), "Household vehicle type holdings and usage: An application of the multiple discrete-continuous extreme value (MDCEV) model", Transportation Research Part B: Methodological, Vol. 40 No. 1, pp. 35-53.

Bhat, C.R., Sen, S. and Eluru, N. (2009), "The impact of demographics, built environment attributes, vehicle characteristics, and gasoline prices on 
household vehicle holdings and use", Transportation Research Part B: Methodological, Vol. 43 No. 1, pp. 1-18.

Cao, X., Mokhtarian, P.L. and Handy, S.L., (2006), "Neighborhood design and vehicle type choice: Evidence from Northern California", Transportation Research Part D: Transport and Environment, Vol. 11 No. 2, pp. 133-145.

Choo, S. and Mokhtarian, P.L. (2004), "What type of vehicle do people drive? The role of attitude and lifestyle in influencing vehicle type choice", Transportation Research Part A: Policy and Practice, Vol. 38 No. 3, pp. 201222.

Dagsvik, J. and Liu, G. (2009), "A framework for analyzing rank-ordered data with application to automobile demand", Transportation Research Part A: Policy and Practice, Vol. 43 No. 1, pp. 1-12.

Dargay, J. and Gately, (1999), "Income effect on car and vehicle ownership, worldwide: 1960-2015", Transportation Research Part A: Policy and Practice, Vol. 33 No. 2, pp. 101-138.

Dargay, J.M. (2001), "The effect of income on car ownership: Evidence of asymmetry", Transportation Research Part A: Policy and Practice, Vol. 35 No. 9, pp. 807-821.

Dargay, J.M. (2002), "Determinants of car ownership in rural and urban areas: A pseudo-panel analysis", Transportation Research Part E: Logistics and Transportation Review, Vol. 38 No. 5, pp. 351-366.

DeMaris, A. (2004), Regression with Social Data: Modeling Continuous and Limited Response Variables, John Wiley \& Sons, Inc., New Jersey.

Ede, F.O. and Panigrahi, B. (2000), "African-American consumer attitudes toward domestic and foreign-made automobiles", Management Research News, Vol. 23, No. 5/6, pp. 1-19.

Hackbarth, A. and Badlener, R. (2013), "Consumer preferences for alternative fuel vehicles: A discrete choice analysis", Transportation Research Part D: Transport and Environment, Vol. 25, pp. 5-17.

Hess, S., Fowler, M., Adler, T. and Bahreinian, A. (2012), "A joint model for vehicle type and fuel type choice: Evidence from a cross-nested logit study", Transportation, Vol. 39, No. 3, pp. 593-625.

Hosmer, D.W. and Lemeshow, S. (2000), Applied Logistic Regression, John Wiley \& Sons, New York.

Kırcova, İ., Altınay, G., Onat, B. and Alver Şahin, Ü. (2012), Otomotiv Ticaretinde Yol Haritasl: Talep Tahmini, 2012-2016 (in Turkish), Otomotiv Distribütörleri Derneği, İstanbul.

Kitapcı, O., Özekicioğlu, H., Kaynar, O. and Taştan, S. (2014), "The effect of economic policies applied in Turkey to the sale of automobiles: Multiple regression and neural network analysis", Procedia - Social and Behavioral Science, Vol. 148, pp. 653-661.

KPMG International. (2014), KPMG's Global Automotive Executive Survey 2014: Strategies for a Fast-Evolving Market, available at: www.kpmg.com/DE/de/Documents/global-automotive-executive-survey2014-KPMG.pdf (accessed January 21, 2015).

KPMG Turkey. (2014), 2014 Automotive Executives Survey: Sustainable Growth in the Turkish Automotive Sector, 2018 Projections, available at: www.kpmg.com/TR/en/IssuesAndInsights/ArticlesPublications/Document 
s/Turkey-2014-Automotive-Executives-Survey.pdf, (accessed January 21, 2015).

Kumar, M. and Krishna Rao, K.V. (2006), "A stated preference study for a car ownership model in the context of developing countries", Transportation Planning and Technology, Vol. 29, No. 5, pp. 409-425.

Lam, W.H.K., MacDonald, C. and Tam, M.L. (2000), "A logit analysis of car ownership in Hong Kong based on stated intention information", HKIE Transactions, Vol. 7, No. 2, pp. 21-28.

Long, J.S. and Freese, J. (2001), Regression Models for Categorical Dependent Variables Using Stata, Stata Press, Texas.

Liu, Y., Tremblay, J.M. and Cirillo, C. (2014), "An integrated model for discrete and continuous decisions with application to vehicle ownership, type and usage choices", Transportation Research Part A: Policy and Practice, Vol. 69, pp. 315-328.

Mabit, S.L. (2014), "Vehicle type choice under the influence of a tax reform and rising fuel prices", Transportation Research Part A: Policy and Practice, Vol. 64, pp. 32-42.

Matas, A. and Raymond, J.L. (2008), "Changes in the structure of car ownership in Spain”, Transportation Research Part A: Policy and Practice, Vol. 42, No. 1, pp. 187-202.

Medlock III, K.B. and Soligo, R. (2002), "Car ownership and economic development with forecasts to the year 2015", Journal of Transport Economics and Policy, Vol. 36, No. 2, pp. 163-188.

Nayum, A. and Klöckner, C.A. (2014), "A comprehensive socio-psychological approach to car type choice", Journal of Environmental Psychology, Vol. 40, pp. 401-411.

Nayum, A., Klöckner, C.A. and Prugsamatz, S. (2013), "Influences of car type class and carbon dioxide emission levels on purchases of new cars: A retrospective analysis of car purchases in Norway", Transportation Research Part A: Policy and Practice, Vol. 48, pp. 96-108.

Nolan, A. (2010), "A dynamic analysis of household car ownership", Transportation Research Part A: Policy and Practice, Vol. 44, No. 6, pp. 446-455.

Nunnally, J.C. (1978), Psychometric Theory, Mc-Graw-Hill, New York.

Oliver, J.D. and Lee, S.H. (2010), "Hybrid car purchase intentions: A cross-cultural analysis", Journal of Consumer Marketing, Vol. 27, No. 2, pp. 96-103.

Özçam, A. and Sağlık Özçam, D. (2012), "A review of econometric estimation of consumer demand for automobiles and the country of origin (COO) effects", Dokuz Eylül Üniversitesi Íktisadi ve İdari Bilimler Dergisi, Vol. 27, No. 1, pp. 97-132.

Potoglou, D. (2006), "Vehicle-type choice and neighbourhood characteristics: An empirical study of Hamilton, Canada", Transportation Research Part D: Transport and Environment, Vol. 13, No. 3, pp. 177-186.

Potoglou, D. and Kanaroglou, P.S. (2008a), "Modelling car ownership in urban areas: A case study of Hamilton, Canada", Journal of Transport Geography, Vol. 16, No. 1, pp. 42-54.

Potoglou, D. and Kanaroglou, P.S. (2008b), "Disaggregate demand analyses for conventional and alternative fueled automobiles: A review, International Journal of Sustainable Transportation, Vol. 2, No. 4, pp. 234-259. 
MMCKS Prieto, M. and Caemmerer, B. (2013), "An exploration of factors influencing car purchasing decisions", International Journal of Retail \& Distribution Management, Vol. 41, No. 10, pp. 738-764.

Qian, L. and Soopramanien, D. (2011), "Heterogeneous consumer preferences for alternative fuel cars in China", Transportation Research Part D: Transport and Environment, Vol. 16, No. 8, pp. 607-613.

Romilly, P., Sang, H. and Liu, X. (2001), "Car ownership and use in Britain: A comparison of the empirical results of alternative cointegration estimation methods and forecasts", Applied Economics, Vol. 33, No. 14, pp. 1803-1818.

Sanko, N., Dissanayeke, D., Kurauchi, S., Maesoba, H., Yamamoto, T. and Morikawa, T. (2014), "Household car and motorcycle ownership in Bangkok and Kuala Lumpur in comparison with Nagoya", Transportmetrica A: Transport Science, Vol. 10, No. 3, pp. 187-213.

Sedzro, K.M., Amewu, G., Darko, J., Nortey, E.N.N. and Dasah, J.B. (2014), "Determinants of automobile purchase and brand choice in Ghana: Multinomial logit approach", Journal of Transnational Management, Vol. 19, No. 4, pp. 303-317.

Tanaka, M., Ida, T., Murakami, K. and Friedman, L. (2014), “Consumers' willingness to pay for alternative fuel vehicles: A comparative discrete choice analysis between the US and Japan", Transportation Research Part A: Policy and Practice, Vol. 70, pp. 194-209.

Thanasuta, K., Patoomsuwan T., Chaimahawong, V. and Chiaravutthi, Y. (2009),"Brand and country of origin valuations of automobiles", Asia Pacific Journal of Marketing and Logistics, Vol. 21, No. 3, pp. 355 - 375

TurkStat (2013), Address Based Population Registration System Statistics 2013, Turkish Statistical Institute, Ankara.

Urbonavičius, S., Dikčius, V. and Časas, R. (2007), "Automobile country of origin related associations in Lithuanian market", Transport, Vol. 22, No. 3, pp. 1-6.

Wong, K.I. (2013), "An analysis of car and motorcycle ownership in Macao", International Journal of Sustainable Transportation, Vol. 7, No. 3, pp. 204225.

Xu, G., Miwa, T., Morikawa, T. and Yamamoto, T. (2015), "Vehicle purchasing behaviors comparison in two-stage choice perspective before and after ecocar promotion policy in Japan", Transportation Research Part D: Transport and Environment, Vol. 34, pp. 195-207.

Yamane, T. (1967), Elementary Sampling Theory, Prentice-Hall, New Jersey.

Yllmaz, Ö. (2001), “Erzurum'da otomobil talebinde etkili olan demografik faktörlerin ekonometrik analizi (in Turkish)", Atatürk Üniversitesi Íktisadi ve Idari Bilimler Dergisi, Vol. 15, No. 1-2, pp. 105-115. 